\title{
The APC gene rs41115 polymorphism is associated with survival in Iranian colorectal cancer patients
}

\author{
Sousan Mir Najd Gerami ${ }^{1}$, Mohammad Hossein Somi ${ }^{1 \oplus}$, Leila Vahedi ${ }^{1}$, Faris Farassati ${ }^{2}$, Roya Dolatkhah $^{3, *(0)}$
}

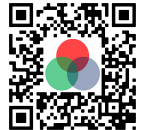

Use your smartphone to scan this QR code and download this article

${ }^{1}$ Liver and Gastrointestinal Diseases Research Center, Tabriz University of Medical Sciences, Tabriz, Iran

${ }^{2}$ Midwest Biomedical Research Foundation, Kansas City, MO, USA

${ }^{3}$ Hematology and Oncology Research Center, Tabriz University of Medical Sciences, Tabriz, Iran

Correspondence

Roya Dolatkhah, Hematology and Oncology Research Center, Tabriz University of Medical Sciences, Tabriz, Iran

Email: royadolatkhah@yahoo.com

History

- Received: Jun 22, 2020

- Accepted: Aug 22, 2020

- Published: Sep 30, 2020

DOI : 10.15419/bmrat.v7i9.627

\section{Check for updates}

\section{Copyright}

(๑) Biomedpress. This is an openaccess article distributed under the terms of the Creative Commons Attribution 4.0 International license.

\begin{abstract}
Introduction: The onset of colorectal cancer is a complex process caused by numerous genetic pathways. APC functions as a "gatekeeper" and its mutations occur at the initiation stage of the colorectal tumorigenesis. The main aim of this study was to investigate common somatic mutations of exon 15 APC genes in patients with colorectal cancer in East Azerbaijan, Iran. Methods: This study was designed and performed as a cross-sectional and case-only study. Tissue biopsies were obtained during colonoscopy and confirmed colorectal carcinoma cases were evaluated. Two hotspot regions of exon 15 for APC mutations were evaluated using PCR amplification and Sanger sequence analysis. Results: The synonymous (p.Thr1475Thr) polymorphism was observed in all patients; 35 patients (61.4\%) had AG genotype and 22 patients (38.6\%) had AA genotype. Also, a missense mutation and two deletions were found. Pearson's correlation test showed a significant correlation between the stage of the disease (rho $=0.23, P \leq 0.05$ ), and anatomical subsite of the tumor with rs41115 polymorphism ( $r$ o $=0.31, P \leq 0.05$ ). Overall comparison of survival function in the different genotypes of the APC gene showed significant differences between groups, and CRCs with AG genotype had 3.24-fold higher hazard of mortality than CRCs with AA genotype (HR $=3.24 ; 95 \% \mathrm{Cl}: 1.21-8.68, \mathrm{P}=0.020)$. Conclusion: $\mathrm{APC}$ mutation plays an important predictive role in overall survival. However, the pattern and type of APC gene have a diverse impact on clinical outcomes in the Asian population. Moreover, in CRC patients the APC mutations were reported to be diverse variants.
\end{abstract}

Key words: Tumor Suppressor Gene, Correlation, Prognosis, Colorectal Cancer, Mutation

\section{INTRODUCTION}

Colorectal cancer (CRC), one of the most prevalent types of cancer, has become a major health problem worldwide. Globally CRC is the third leading cause of death, with more than 1.8 million new cases and 800,000 deaths registered each year ${ }^{1}$. Recently, CRC has become the third most common cause of cancer in males and the second most common in females in $\mathrm{Iran}^{2}$. In the East Azerbaijan Province (Northwest of Iran), there are high incidence rates of mostly gastrointestinal cancers, with CRC as the second most common cancer in both sexes and with an increasing trend in age standardized incidence rates during the last decade ${ }^{3-5}$.

About $70-80 \%$ of colorectal cancers arise as sporadic form; only 5 - $10 \%$ of germline mutations lead to hereditary colorectal cancer ${ }^{6}$. Sporadic CRC occurs in old age and is most common after the age of $50^{7}$. The onset of colorectal cancer is a complex process caused by numerous mechanisms including three major genetic pathways: Chromosomal Instability (CIN) Pathway, CPG Island Methylator Phenotype (CIMP), and Microsatellite Instability (MSI) Pathway ${ }^{8,9}$.
Tumor suppressor genes (such as APC, P53, DCC, $M C C$ and SMAD4), oncogenes (such as CTNNB1 (catenin protein encoder), K-Ras and $c-m y c$ ), and encoding repair system genes (such as $h M L H 1$ and $h M S H 2$ ) are genetic factors that play a role in the development of colorectal cancer by different mechanisms ${ }^{10}$. The APC gene spans about $100 \mathrm{~kb}$ of genomic DNA, has a coding region of 8,532 base pairs, is located on chromosome 5q21-22, and contains 21 exons. Exon 15 is the largest exon covering over $75 \%$ of the coding sequence of APC. The APC gene encodes a $312-k D a$ protein that performs diverse cellular functions such as microtubule stability, cell-cell interaction, cell polarity, cell migration and apoptosis ${ }^{11-13}$.

The APC protein has several domains in its structure through which it interacts with various proteins, and this reflects the different functions. The APC protein exerts its main role in the Wnt signal transmission pathway and is a regulator of the cell cycle. APC functions as a "gatekeeper" and its mutations occur at the initiation stage of colorectal tumorigenesis ${ }^{14}$. Mutations in the APC gene are often frame-shifts, insertions, or deletions which introduce premature stop 
codons and lead to the production of a truncated $A P C$ protein ${ }^{15}$. The mutant form of APC is found in both sporadic and inherited colorectal cancer as nonsense point mutation or single nucleotide polymorphisms (SNPs) ${ }^{16}$. However, $60 \%$ of all mutations that occur in the APC gene (45 - 35\% of all sporadic colon tumors) are in the MCR region of Exon 15, with this region containing about $10 \%$ of the protein coding sequence.

The main aim of this study was to investigate common somatic mutations of exon 15 APC gene in patients with colorectal cancer in East Azerbaijan (located in Northwest of Iran), known to have the highest Azeri Ethnic population. In addition, the aims are to assess any clinicopathological aspects with mutation patterns of $A P C$, as well as to evaluate their prognostic impact in CRC.

\section{MATERIALS AND METHODS}

\section{Patients}

This study was designed and performed as a crosssectional and case-only study, with 60 colorectal cancer patients recruited in East Azerbaijan during 2019. Tissue samples were obtained by tumor tissue biopsies during colonoscopy and were evaluated after pathologic confirmation of colorectal carcinoma. All patients signed informed consent to participate in the study. Pathology reports were used to confirm the diagnosis, with all available cytology, histology, necropsy and immunohistochemistry considered for assessment. Tumor stage was determined by TNM classification of malignant tumors.

\section{Molecular Analysis}

DNA was extracted from frozen tumor tissues and normal cells using the YTA kit (Yekta Tajhiz, Iran), following the manufacturer's instructions. The extracted DNA concentration was measured using a Nano-Drop spectrophotometer (Thermo Fisher Scientific, Waltham, MA, USA). Two hotspot regions in the MCR region of exon 15 were evaluated for APC mutations using PCR amplification and automatic DNA sequence analysis method. The primer design was based on published sequences for the genotyping procedure of $A P C$ mutation using genomic DNA ${ }^{14}$. The primer sequences are shown in Table 1. The PCR program included a hot start denaturation step at 95 ${ }^{\circ} \mathrm{C}$ for $5 \mathrm{~min}$, then 35 amplification cycles of denaturation at $95{ }^{\circ} \mathrm{C}$ for $45 \mathrm{~s}$, annealing at $62^{\circ} \mathrm{C}$ for exon $15(1), 60^{\circ} \mathrm{C}$ for exons 15 (2) for $60 \mathrm{~s}$, and elongation at $72{ }^{\circ} \mathrm{C}$ for $45 \mathrm{~s}$, and ending with a final extension at 72 ${ }^{\circ} \mathrm{C}$ for $7 \mathrm{~min}$.

\section{Sequencing Analysis}

After amplification, the purified PCR product was sequenced in both directions. The Sanger sequencing method was used for mutation detection in samples. The chromatogram files of the sequencing results were viewed and checked for quality by Finch TV1.4 software (www. geospiza.com). The Basic Local Alignment Search Tool of the NCBI webpage (BLAST; https ://blast.ncbi.nlm.nih.gov/Blast.cgi) was used to search for highly similar sequences available in the GenBank database retrieved from NCBI. Then, the alignment of the sample sequence with similar sequences was performed.

\section{Statistical Analysis}

Descriptive data were obtained using SPSS software (version 24; IBM, Armonk, NY, USA). Pearson's ChiSquare test was used to assess and report the Likelihood ratio for any correlation between defined variables (age, sex, stage, grade, morphologic type, subsite of the tumor, and positive family history) and $A P C$ gene pattern. For survival analysis, the outcome of interest was overall survival (OS), defined as the time of CRC diagnosis to date of death and/or last follow-up time. OS and statistical significance of survival function was assessed using the Kaplan-Meier method and the log-rank test.

\section{RESULTS}

\section{Descriptive analysis results}

From the 60 confirmed colorectal cancers, 57 cases were eligible to enroll in the study and had enough tissue samples that were assessable to perform molecular tests. The age range was between 27-90 years old, with age mean of 63.32 (SD 15.17); 13 cases (22.8\%) were $\leq 50$ years old while $44(77.2 \%)$ were over 50 years old. The most common age group was the 5 th decade $(n=13,22.8 \%)$ and 7 th decade $(n=13,22.8 \%)$. From these, 44 CRCs (77.2\%) were male and 13 cases $(22.8 \%)$ were female. In 21 cases $(36.8 \%)$, the tumor was located in the right colon; in $17(29.8 \%)$ the tumor was in the left colon, and in 19 cases (33.3\%) the tumors were in the rectum. Most of the CRCs were adenocarcinoma $(n=50,87.7 \%)$, and $47.4 \%$ of CRCs $(n=27)$ were in grade I (well-differentiated) stage of disease. From 57 CRCs, 2 cases (3.5\%) had a positive family history of colorectal polyps, 13 CRCs (22.8\%) had at least one relative with colorectal carcinoma, and 15 patients (26.3\%) had a positive family history of other gastrointestinal system cancers. Pearson's correlation test showed that there was a significant correlation between the stage of the disease and 
Table 1: Sequence Primers used for study of mutation of MCR region

\begin{tabular}{lllcc}
\hline & Primer sequence & TM $\left({ }^{\circ} \mathbf{C}\right)$ & $\begin{array}{c}\text { Product Length } \\
\text { (bp) }\end{array}$ \\
Exon15(1) & Forward & $\begin{array}{l}\text { 5'-CAAGCAGTGAGAATACGTCCACAC- } \\
\text { 3' }\end{array}$ & 61.90 & 808 \\
& Reverse & $\begin{array}{l}\text { 5'-AGAACCTGGACCCTCTGAACTGCA- } \\
\text { 3' }\end{array}$ & 65.42 & \\
Exon15(2) & Forward & 5'-TCCGTTCAGAGTGAACCATGCA- & 62.19 & 626 \\
& 3' & & \\
& Reverse & 5'-AGCTGACTTGGTTTCCTTGCCA-3' & 62.68 & \\
\hline
\end{tabular}

rs41115 polymorphism (rho correlation $=0.23, \mathrm{P} \leq$ $0.05)$. Also, a significant correlation between anatomical subsite of tumor and rs41115 was found (rho correlation $=0.31, \mathrm{P} \leq 0.05)$. There was no significant correlation between other variables and rs41115 polymorphism.

\section{Molecular tests results}

Genomic DNA sequencing of codon 1213 to 1613 of APC gene (MCR region in exon 15) revealed a total of 4 different changes in all sporadic CRC patients (Table 3), including a nonsense G4425A mutation (Thr1475Thr, rs41115), a missense T4341G mutation (Ser1447Arg), a microdeletion 4506delA, and a five-nucleotide deletion 4087-4091delAAAAG. The synonymous (p.Thr1475Thr) polymorphism was observed in all patients; 35 patients (61.4\%) had the AG genotype and 22 patients (38.6\%) had the AA genotype. Deletion of five nucleotides in the MCR region of exon 15 was observed in case 43; however, this case did not have any different prognostic and clinicopathological aspects.

\section{Survival analysis results}

Kaplan-Meier survival analysis was performed and the survival curve was created for OS function. The OS proportion was $54.4 \%$ (26 cases died). The mean OS time was 49.99 months (95\% CI: 45.62 - 54.35) and the median OS was 48.40 months (95\% CI: $39.04-$ 57.76). Overall comparison of survival function in the different genotypes was assessed using Kaplan Meyer and Log-rank (Mantel-Cox). The tests showed that there were significant differences between groups ( $P$ Log-rank = 0.016) (Figure 2). The AG genotype had worse OS than AA genotype; mean OS time was 38.72 (95\% CI: $36.61-40.83$ ) for AG genotype while it was 48.81 (95\% CI: 43.98 - 53.63) for AA genotype. Cox regression analysis also showed that CRCs with AG genotype had 3.24 times higher hazard of mortality than CRCs with AA genotype (HR $=3.24 ; 95 \% \mathrm{CI}$ : $1.21-8.68, \mathrm{P}=0.020)$.

\section{DISCUSSION}

Bi-allelic mutation of adenomatous polyposis coli $(A P C)$ gene is an initiative process in chromosomal instability pathway of colorectal cancer pathogenesis, which leads to cancer progression, K-Ras mutation, and finally TP53 gene alteration ${ }^{9,17}$. APC is a tumor suppressor gene; for complete inactivation and transcription of the gene, the loss of both copies is required. APC gene, as a tumor suppressor gene, may be dysregulated at both somatic and germline levels in CRC pathogenesis ${ }^{18}$. About $75 \%$ of both germline and somatic mutations are located on exon 15 ; this gene consists of more than 8,000 nucleotides and spans 21 exons ${ }^{18}$. However, APC gene somatic mutations may cause non-functional proteins, and even these small defects play an important role in colorectal cancer pathogenesis ${ }^{19}$.

We aimed to investigate common somatic mutations in exon 15 of APC genes in colorectal cancer patients in East Azerbaijan, Iran. Moreover, we sought to assess any clinicopathological aspects related to the mutation patterns and evaluate the prognostic impact of APC gene pattern in 57 sporadic colorectal cancers. As we did not have any background knowledge about the pattern and spectrum of the APC gene in our CRC population, we decided to perform a case-only study and detect the most common somatic mutations by focusing on exon 15 of the APC gene.

The MCR region of exon 15 was amplified and standard mutational analysis by Sanger sequencing was performed. DNA sequence data from chromatograms using the Finch TV and BLAST were analyzed. The results revealed only 4 changes, with all patients showing a nonsense mutation. As well, a missense mutation and two deletions were found. One case showed five-nucleotide deletion; however, this case did not have any different prognostic and clinicopathological 
Table 2: Descriptive results of 57 sporadic colorectal cancer, and correlation with APC gene pattern in East Azerbaijan

\begin{tabular}{|c|c|c|c|c|c|c|}
\hline Variable & & Number (\%) & $\begin{array}{c}\text { Rs41115 } \\
\text { AG genotype } \\
\mathrm{N}=35(61.4 \%)\end{array}$ & $\begin{array}{c}\text { Rs41115 } \\
\text { AA genotype } \\
\begin{array}{c}\mathrm{N}=22 \\
(38.6 \%)\end{array}\end{array}$ & $\begin{array}{c}\text { Pearson's } \\
\text { rho }^{\star}\end{array}$ & $\mathbf{P}$ \\
\hline \multirow[t]{2}{*}{ Age } & $\leq 50$ & $13(22.8 \%)$ & 8 & 5 & 0.2 & 0.091 \\
\hline & $>50$ & $44(77.2 \%)$ & 27 & 17 & & \\
\hline \multirow[t]{2}{*}{ Sex } & Male & $44(77.2 \%)$ & 8 & 5 & 0.2 & 0.091 \\
\hline & Female & $13(22.8 \%)$ & 27 & 17 & & \\
\hline \multirow[t]{4}{*}{ Stage } & I & $10(17.5 \%)$ & 7 & 3 & 0.23 & 0.056 \\
\hline & II & $11(19.3 \%)$ & 5 & 6 & & \\
\hline & III & $6(10.5 \%)$ & 5 & 1 & & \\
\hline & IV & $30(52.6 \%)$ & 18 & 12 & & \\
\hline \multirow[t]{4}{*}{ Grade } & I & $21(36.8 \%)$ & 13 & 8 & 0.09 & 0.486 \\
\hline & II & $14(24.6 \%)$ & 8 & 6 & & \\
\hline & III & $10(17.5 \%)$ & 4 & 6 & & \\
\hline & IV & $12(21.1 \%)$ & 10 & 2 & & \\
\hline \multirow{2}{*}{$\begin{array}{l}\text { Morphological } \\
\text { Type }\end{array}$} & Adenocarcin & $50(87.7 \%)$ & 32 & 18 & 0.14 & 0.290 \\
\hline & Others & $7(12.3 \%)$ & 3 & 4 & & \\
\hline \multirow[t]{3}{*}{ Subsite } & $\begin{array}{l}\text { Right } \\
\text { Colon }\end{array}$ & $21(36.8 \%)$ & 11 & 10 & 0.31 & 0.029 \\
\hline & Left Colon & $17(29.8 \%)$ & 9 & 8 & & \\
\hline & Rectum & $19(33.3 \%)$ & 15 & 4 & & \\
\hline \multirow{2}{*}{$\begin{array}{l}\text { Family History } \\
\text { of Polyps }\end{array}$} & No & $54(94.7 \%)$ & 33 & 21 & 0.042 & 0.757 \\
\hline & Yes & $2(3.5 \%)$ & 1 & 1 & & \\
\hline \multirow{2}{*}{$\begin{array}{l}\text { Family History } \\
\text { of CRC }\end{array}$} & No & $44(77.2 \%)$ & 27 & 17 & 0.20 & 0.091 \\
\hline & Yes & $13(22.8 \%)$ & 8 & 5 & & \\
\hline \multirow{2}{*}{$\begin{array}{l}\text { Family History } \\
\text { of other GI } \\
\text { cancers }\end{array}$} & No & $42(73.7 \%)$ & 23 & 19 & 0.23 & 0.088 \\
\hline & Yes & 15 (26.3\%) & 12 & 3 & & \\
\hline
\end{tabular}

Abbreviations: Rho: Likelihood Ratio; Pearson Chi-Square test analyzing Continuity Correlation ; P value $\leq 0.05$ 
Table 3: Frequency of APC gene pattern, nucleotide substitution, and amino acid change in $\mathbf{5 7}$ colorectal cancers

\begin{tabular}{|c|c|c|c|}
\hline Sample & DNA change & Amino acid change & Type \\
\hline C16 & $\mathrm{ACG}>\mathrm{ACA}(\mathrm{G}>\mathrm{A})$ & T1475T(Thr1475Thr) & Transition \\
\hline C28 & $\mathrm{ACG}>\mathrm{ACA}(\mathrm{G}>\mathrm{A})$ & T1475T(Thr1475Thr) & Transition \\
\hline C37 & $\mathrm{ACG}>\mathrm{ACA}(\mathrm{G}>\mathrm{A})$ & T1475T(Thr1475Thr) & Transition \\
\hline C55 & $\mathrm{ACG}>\mathrm{ACA}(\mathrm{G}>\mathrm{A})$ & T1475T(Thr1475Thr) & Transition \\
\hline $\mathrm{C} 80$ & $\mathrm{ACG}>\mathrm{ACA}(\mathrm{G}>\mathrm{A})$ & T1475T(Thr1475Thr) & Transition \\
\hline C92 & $\mathrm{ACG}>\mathrm{ACA}(\mathrm{G}>\mathrm{A})$ & T1475T(Thr1475Thr) & Transition \\
\hline C95 & $\mathrm{ACG}>\mathrm{ACA}(\mathrm{G}>\mathrm{A})$ & T1475T(Thr1475Thr) & Transition \\
\hline C97 & $\mathrm{ACG}>\mathrm{ACA}(\mathrm{G}>\mathrm{A})$ & T1475T(Thr1475Thr) & Transition \\
\hline C107 & $\mathrm{ACG}>\mathrm{ACA}(\mathrm{G}>\mathrm{A})$ & T1475T(Thr1475Thr) & Transition \\
\hline C109 & $\mathrm{ACG}>\mathrm{ACA}(\mathrm{G}>\mathrm{A})$ & T1475T(Thr1475Thr) & Transition \\
\hline C115 & $\mathrm{ACG}>\mathrm{ACA}(\mathrm{G}>\mathrm{A})$ & T1475T(Thr1475Thr) & Transition \\
\hline C117 & $\mathrm{ACG}>\mathrm{ACA}(\mathrm{G}>\mathrm{A})$ & T1475T(Thr1475Thr) & Transition \\
\hline $\mathrm{C} 118$ & $\mathrm{ACG}>\mathrm{ACA}(\mathrm{G}>\mathrm{A})$ & T1475T(Thr1475Thr) & Transition \\
\hline $\mathrm{C} 147$ & $\mathrm{ACG}>\mathrm{ACA}(\mathrm{G}>\mathrm{A})$ & T1475T(Thr1475Thr) & Transition \\
\hline C43 & 4087-4091delAAAAG & & Frame shift change \\
\hline C109 & 4506delA & & Frame shift change \\
\hline $\mathrm{C} 110$ & AGT $>A G G(T>G)$ & SER1447ARG(S1447R) & Transversion \\
\hline
\end{tabular}

aspects. Relying on the findings of only one case cannot be concluded as strong evidence of the APC gene mutation pattern. The overall comparison of survival function in the different genotypes of $A P C$ gene showed significant differences between the groups $(\mathrm{P}$ Log-rank $=0.016$ ). These findings provide rationale for further comprehensive studies on the APC gene in CRC, particularly with a larger sample size and inclusion of other molecular techniques.

It is well-recognized that the main product of the APC gene is involved mainly in the Wnt signaling pathway and has diverse functions in this pathway beyond regulation of Wnt components ${ }^{18}$. Also, APC gene mutation mainly affects proteins in the Wnt signaling pathway, and can lead to cell division excess in a few cancers, including colorectal cancer ${ }^{19}$. However, in CRC patients the APC mutation was reported as diverse variants ${ }^{20}$. On the other hand, the Wnt signaling pathway is closely associated with BRAF mutation. Several studies have revealed very low incidence $(0 \%-3.7 \%)$ of BRAF mutation in Asian CRCs ${ }^{21,22}$. Since we did not find any BRAF mutations in the same CRC samples as our previous study, this may evidence of the absence of any APC truncated mutation pat$\operatorname{tern}^{21}$.
The overall frequency of the $A P C$ gene mutation in sporadic colorectal cancer is about $25-30 \%$, but some reports from Iran have revealed a different mutation profile ${ }^{23-26}$. This may be because of geneenvironmental interaction factors and predominantly because of the heterogeneous nature of colorectal cancer. However, the APC gene mutation location is somehow distinct and diverse, and most commonly revealed as a frameshift mutation in exon 15 and found in familial adenomatous polyposis (FAP) patients. It is well-established that the $W$ nt signaling pathway is dysregulated very early in conventional adenomas by mutation of $A P C^{9,17}$. Although many research studies were performed on the APC germline mutation pathogenesis, especially in FAP, conclusions about mutations and/or DNA polymorphisms such as SNP (single nucleotide polymorphism) pattern, as well as pathogenesis of the APC gene, have not been clear in CRC ${ }^{27,28}$. However, a few studies have revealed that the APC gene may have a different performance, with a few detected SNPs in exon 15 of this tumor suppressor gene as a germline mutation ${ }^{19,29-32}$. A most recent study on common gene mutation profile in CRCs showed point mutations in exon 16 of $A P C$ gene with a $19.7 \%$ prevalence ${ }^{29,33-35}$. 
A

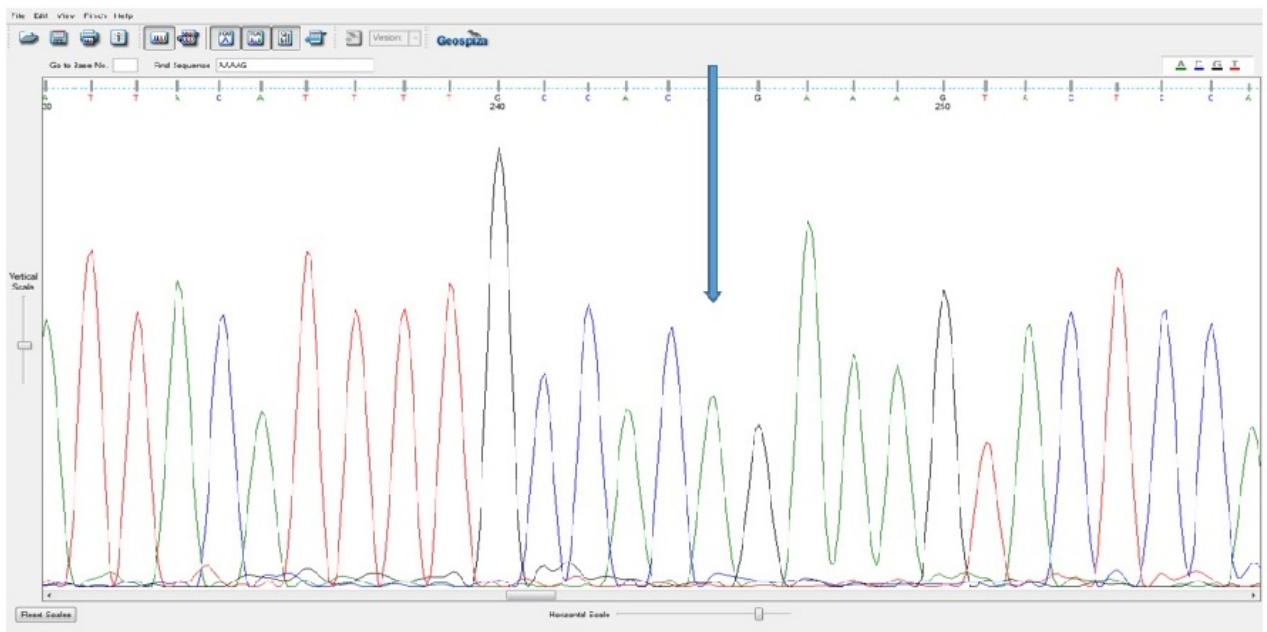

B

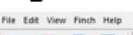

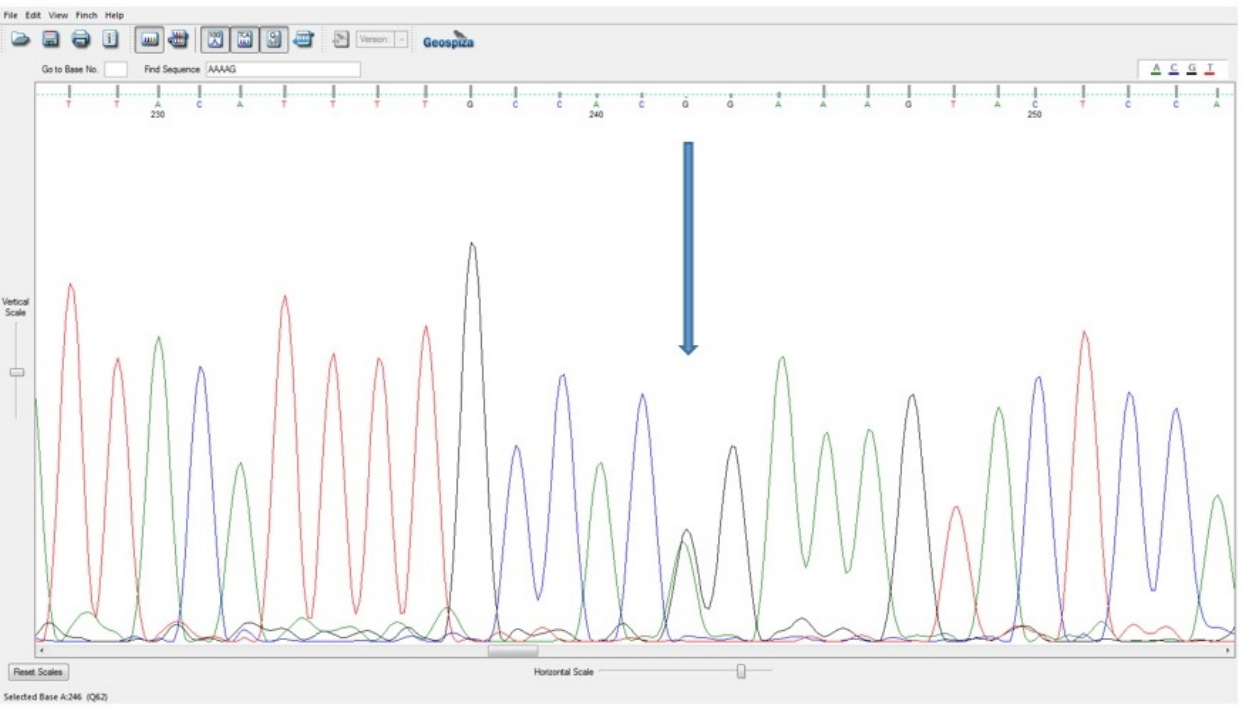

Figure 1: Sequence analysis and multiple alignment results of APC Gene in colorectal cancer. A: Rs41115 polymorphism AA genotype; B: Rs41115 polymorphism AG genotype

Although APC has been well-recognized as an initiator gene in colorectal cancer carcinogenesis, its prognostic role has not been well-established. Indeed, there is still a discrepancy in the impact of APC mutation and pattern on CRC prognosis. Few studies were performed regarding the survival status in patients with APC mutation. However, those results revealed that for the majority of colorectal cancer patients, inactivation of APC tumor suppressor gene, as one allelic mutation, did not impact the OS by itself. Only APC bi-allelic mutation and/or APC partnership with other mutations (K-ras, P53) have prognostic impact ${ }^{7}$. This has been reported from a few studies that show that CRCs with mutations in Wnt and APC pathways had significantly worse OS and poorer median survival ${ }^{17,18}$. Siraj et al. revealed that $A P C$ mutation represents an important predictive factor in OS; however, pattern and type of APC gene did not have any impact on clinical outcomes in the Middle Eastern population ${ }^{36}$. Also, another report from the UK revealed that APC did not affect prognosis in their cohort study. However, $K$-ras serves as an independent prognostic variable in $\mathrm{CRCs}^{37}$. The results of our study reveal that there are significant survival function differences between the two genotypes of the $A P C$ gene in East Azerbaijan.

Because of limited molecular detection techniques and low sample size, we found only a $5 \%$ mutation 


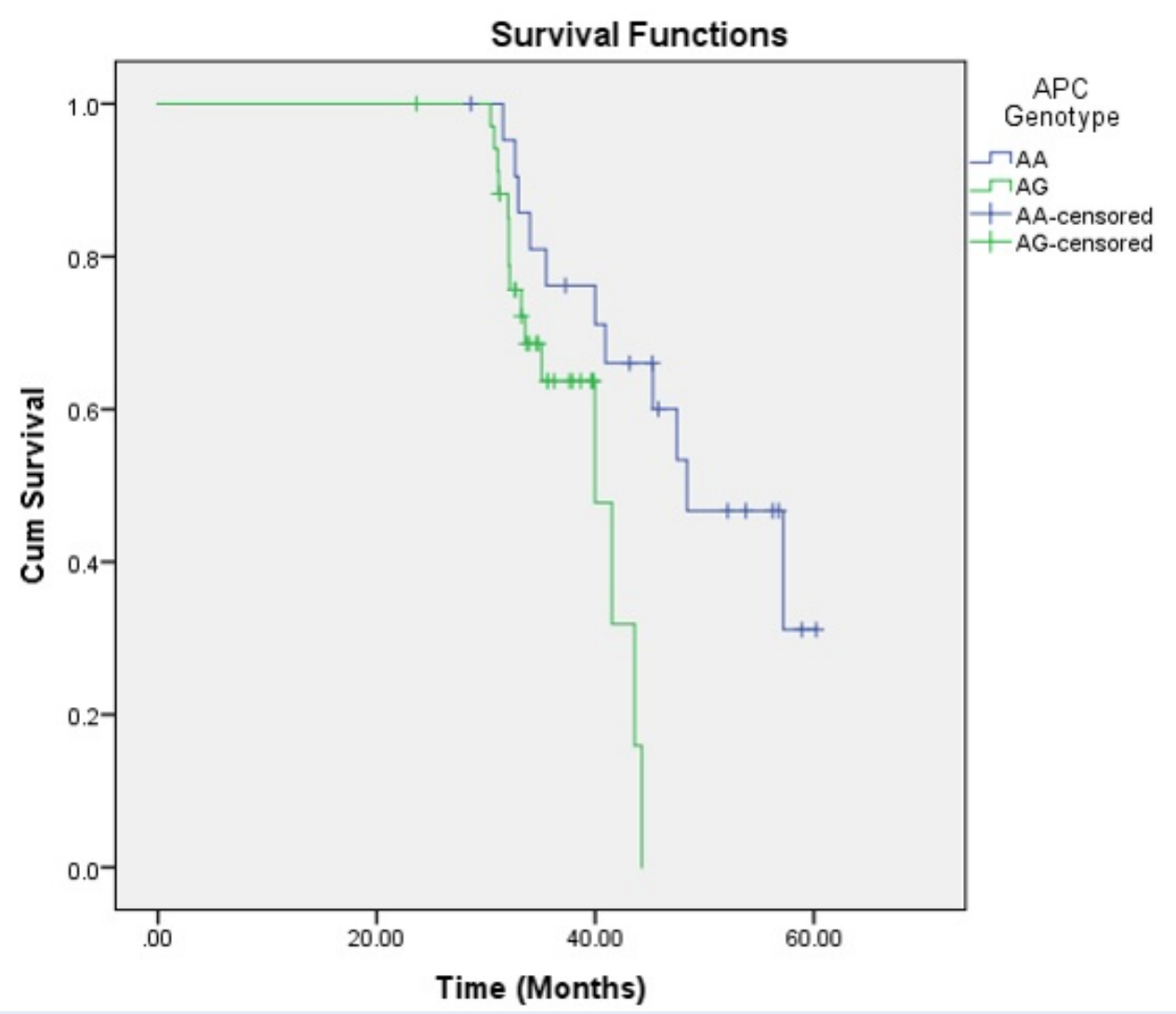

Figure 2: Survival function comparison between different APC genotypes in 57 colorectal cancers, $\mathrm{P}$ Logrank $=\mathbf{0 . 0 1 6}$.

in 57 CRCs in our study. Genome-wide association studies or epigenetic change detection methods should be performed in larger sample sizes to identify the exact molecular pathways involved in CRC in our region. We did not access the Next Generation Sequencing (NGS) analysis and/or whole-genome sequencing. NGS analysis has the advantage of sequencing a few hundred genes at the hotspot regions of mentioned genes, compared with Sanger sequencing. Thus, this was the main limitation of the study herein.

\section{CONCLUSION}

The prognostic impact of APC tumor suppressor gene mutation was not well-established yet. Proper identification of the different molecular pathways in CRC pathogenesis and the different allelic variants of the responsible genes, along with assessing geneenvironmental factors and their interaction, are the main key elements used to define the high-risk populations. As well, genetic susceptibility in different ethnics warrants further investigation in future studies.

\section{ABBREVIATIONS}

APC: Adenomatous polyposis coli CIMP: CPG Island Methylator Phenotype

CIN: Chromosomal Instability

CRC: Colorectal Cancer

MCR Region: mutation cluster region

MSI: Microsatellite Instability

OS: Overall Survival

PCR: Polymerase Chain Reaction

SNP: single nucleotide polymorphism

\section{ACKNOWLEDGMENTS}

We would like to thank to all the patients who took part in this study.

\section{AUTHOR'S CONTRIBUTIONS}

SMNG, and RD: performed the significant contributions to conceptualization and design; and the acquisition, analysis, and interpretation of the data. MHS, LV, FF: performed the drafting of the article and critical revision for important intellectual content. All the 
authors approved the final version of the manuscript to be published.

\section{FUNDING}

The study has been funded as a research grant, by Ministry of Health and Medical Education, Deputy of Research and Technology (Grant number: 700/98, 2015.03.14 [1394/12/24]) from Iran Ministry of Health. Also this study has been supported from Hematology and Oncology Research Center of Tabriz University of Medical Sciences (ID: 60156).

\section{AVAILABILITY OF DATA AND MATERIALS}

Data and materials used and/or analyzed during the current study are available from the corresponding author on reasonable request.

\section{ETHICS APPROVAL AND CONSENT TO PARTICIPATE}

This study was conducted in accordance with the amended Declaration of Helsinki. The institutional review board approved the study, and all participants provided written informed consent.

All patients were signed consent forms, and all personal information are confidential. The Ethics Committee of Tabriz University of Medical Sciences, has been evaluated and confirmed this study as a Research Project. (Permit Number: IR.TBZMED.REC.1397.441).

\section{CONSENT FOR PUBLICATION}

Not applicable.

\section{COMPETING INTERESTS}

The authors declare that they have no competing interests.

\section{REFERENCES}

1. Ferlay J, Colombet M, Soerjomataram I, Mathers C, Parkin DM, Pineros $M$, et al. Estimating the global cancer incidence and mortality in 2018: GLOBOCAN sources and methods. Int J Cancer. 2019;144(8):1941-1953. PMID: 30350310. Available from: https://doi.org/10.1002/ijc.31937.

2. Roshandel G, Ghanbari-Motlagh A, Partovipour E, Salavati F, Hasanpour-Heidari S, Mohammadi G, et al. Cancer incidence in Iran in 2014: Results of the Iranian National Populationbased Cancer Registry. Cancer Epidemiol. 2019;;61:50-58. PMID: 31132560. Available from: https://doi.org/10.1016/j. canep.2019.05.009.

3. Somi MH, Dolatkhah R, Sepahi S, Belalzadeh M, Naghashi S, Asghari Jafarabadi M. A 12-year trend analysis of the incidence of gastrointestinal cancers in East Azerbaijan: last updated results of an ongoing population-based cancer registry. BMC Cancer. 2019;19(1):782. PMID: 31391032. Available from: https://doi.org/10.1186/s12885-019-6008-3.

4. Somi MH, Dolatkhah R, Sepahi S, Belalzadeh M, Sharbafi J, Abdollahi $\mathrm{L}$, et al. Cancer incidence in the East Azerbaijan province of Iran in 2015-2016: results of a population-based cancer registry. BMC Public Health. 2018;18(1):1266. PMID: 30453968. Available from: https://doi.org/10.1186/s12889018-6119-9.

5. Dolatkhah R, Somi MH, Kermani IA, Ghojazadeh M, Jafarabadi $M A$, Farassati $F$, et al. Increased colorectal cancer incidence in Iran: a systematic review and meta-analysis. BMC Public Health. 2015;15:997. PMID: 26423906. Available from: https://doi.org/10.1186/s12889-015-2342-9.

6. Kasubova I, Kalman M, Jasek K, Burjanivova T, Malicherova B, Vanochova A, et al. Stratification of patients with colorectal cancer without the recorded family history. Oncol Lett. 2019;17(4):3649-3656. PMID: 30881489. Available from: https://doi.org/10.3892/ol.2019.10018.

7. Schell MJ, Yang M, Teer JK, Lo FY, Madan A, Coppola D, et al. A multigene mutation classification of 468 colorectal cancers reveals a prognostic role for APC. Nature communications. 2016;7:11743. PMID: 27302369. Available from: https: //doi.org/10.1038/ncomms11743.

8. Dolatkhah R, Somi MH, Shabanloei R, Farassati F, Fakhari A, Dastgiri S. Main Risk Factors Association with Proto-Oncogene Mutations in Colorectal Cancer. Asian Pacific Journal of Cancer Prevention. 2018;19(8):2183-2190.

9. Dolatkhah R, Somi MH, Bonyadi MJ, Asvadi Kermani I, Farassati F, Dastgiri S. Colorectal cancer in iran: molecular epidemiology and screening strategies. J Cancer Epidemiol. 2015;2015:643020. PMID: 25685149. Available from: https: //doi.org/10.1155/2015/643020.

10. Brewster SF, Browne S, Brown KW. Somatic allelic loss at the DCC, APC, nm23-H1 and p53 tumor suppressor gene loci in human prostatic carcinoma. The Journal of urology. 1994;151(4):1073-1077. Available from: https://doi.org/10. 1016/S0022-5347(17)35186-8.

11. Xicola RM, Manojlovic Z, Augustus GJ, Kupfer SS, Emmadi $\mathrm{R}$, Alagiozian-Angelova V, et al. Lack of APC somatic mutation is associated with early-onset colorectal cancer in African Americans. Carcinogenesis. 2018;39(11):1331-1341. PMID: 30239619. Available from: https://doi.org/10.1093/carcin/ bgy122.

12. Ye C, Qi L, Li X, Wang J, Yu J, Zhou B, et al. Targeting the NAD(+) salvage pathway suppresses APC mutation-driven colorectal cancer growth and Wnt/beta-catenin signaling via increasing Axin level. Cell Commun Signal. 2020;18(1):16. PMID: 32005247. Available from: https://doi.org/10.1186/s12964020-0513-5.

13. Zhang M, Yang D, Gold B. The Adenomatous Polyposis Coli (APC) mutation spectra in different anatomical regions of the large intestine in colorectal cancer. Mutat Res. 2018;810:15. PMID: 29751128. Available from: https://doi.org/10.1016/j. mrfmmm.2018.04.003.

14. Hasanpour M, Galehdari H, Masjedizadeh A, Ajami N. A unique profile of adenomatous polyposis coli gene mutations in Iranian patients suffering sporadic colorectal cancer. Cell J. 2014;16(1):17-24.

15. Hankey W, Frankel WL, Groden J. Functions of the APC tumor suppressor protein dependent and independent of canonical WNT signaling: implications for therapeutic targeting. Cancer Metastasis Rev. 2018;37(1):159-172. PMID: 29318445. Available from: https://doi.org/10.1007/s10555-017-9725-6.

16. Su HX, Zhou HH, Wang MY, Cheng J, Zhang SC, Hui F, et al. Mutations of C-reactive protein (CRP) -286 SNP, APC and p53 in colorectal cancer: implication for a CRP-Wnt crosstalk. PLoS One. 2014;9(7):e102418. PMID: 25025473. Available from: https://doi.org/10.1371/journal.pone.0102418.

17. Fennell L, Kane A, Liu C, McKeone D, Fernando W, Su C, et al. APC Mutation Marks an Aggressive Subtype of BRAF Mutant Colorectal Cancers. Cancers (Basel) . 2020;12(5). PMID: 32384699. Available from: https://doi.org/10.3390/ cancers12051171.

18. Zhang L, Shay JW. Multiple Roles of APC and its Therapeutic Implications in Colorectal Cancer. J Natl Cancer Inst. 
2017;109(8). Available from: https://doi.org/10.1093/jnci/ djw332.

19. Norollahi SE, Hamidian SMT, Khazaee Kohpar Z, Azadi R, Rostami P, Vahidi S, et al. The fluctuation of APC gene in WNT signaling with adenine deletion of adenomatous polyposis coli, is associated in colorectal cancer. Journal of Coloproctology. 2020;40(2):135-142. Available from: https://doi.org/10.1016/j. jcol.2019.11.487.

20. Aghabozorgi AS, Bahreyni A, Soleimani A, Bahrami A, Khazaei $M$, Ferns $G A$, et al. Role of adenomatous polyposis coli (APC) gene mutations in the pathogenesis of colorectal cancer; current status and perspectives. Biochimie. 2019;157:6471. PMID: 30414835 . Available from: https://doi.org/10.1016/j. biochi.2018.11.003.

21. Dolatkhah R, Somi MH, Asvadi Kermani I, Bonyadi M, Sepehri B, Boostani K, et al. Association between proto-oncogene mutations and clinicopathologic characteristics and overall survival in colorectal cancer in East Azerbaijan, Iran. Onco Targets Ther. 2016;9:7385-7395. PMID: 27994469. Available from: https://doi.org/10.2147/OTT.S116373.

22. Yari A, Samoudi A, Afzali A, Karam ZM, Karimaldini NK, Abadi MFS, et al. Mutation Status and Prognostic Value of KRAS and BRAF in Southeast Iranian Colorectal Cancer Patients: First Report from Southeast of Iran. J Gastrointest Cancer. 2020;PMID: 32495109. Available from: https://doi.org/10.1007/s12029020-00426-8.

23. Ashktorab H, Mokarram P, Azimi H, Olumi H, Varma S, Nickerson $\mathrm{ML}$, et al. Targeted exome sequencing reveals distinct pathogenic variants in Iranians with colorectal cancer. Oncotarget. 2017;8(5):7852-7866. PMID: 28002797. Available from: https://doi.org/10.18632/oncotarget.13977.

24. Hasanpour M, Galehdari H, Masjedizadeh A, Ajami N. A unique profile of adenomatous polyposis coli gene mutations in Iranian patients suffering sporadic colorectal cancer. Cell J. 2014;16(1):17-24

25. Nassiri M, Kooshyar MM, Roudbar Z, Mahdavi M, Doosti $M$. Genes and SNPs associated with non-hereditary and hereditary colorectal cancer. Asian Pac J Cancer Prev. 2013;14(10):5609-5614. PMID: 24289550. Available from: https://doi.org/10.7314/APJCP.2013.14.10.5609.

26. Pouya F, Mojtabanezhad Shariatpanahi A, Ghaffarzadegan $K_{t}$ Tabatabaee Yazdi SA, Golmohammadzadeh H, Soltani G, et al. A novel large germ line deletion in adenomatous polyposis coli (APC) gene associated with familial adenomatous polyposis. Mol Genet Genomic Med. 2018;6(6):1031-1040. PMID: 30259713. Available from: https://doi.org/10.1002/mgg3.479.

27. Rafiemanesh H, Pakzad R, Abedi M, Kor Y, Moludi J, Towhidi F, et al. Colorectal cancer in Iran: Epidemiology and morphology trends. EXCLI J. 2016;15:738-744.
28. Malekzadeh R, Bishehsari F, Mahdavinia M, Ansari R. Epidemiology and molecular genetics of colorectal cancer in iran: a review. Arch Iran Med. 2009;12(2):161-169.

29. Chen SP, Tsai ST, Jao SW, Huang YL, Chao YC, Chen YL, et al. Single nucleotide polymorphisms of the APC gene and colorectal cancer risk: a case-control study in Taiwan. BMC Cancer. 2006;6:83. PMID: 16569251. Available from: https://doi. org/10.1186/1471-2407-6-83.

30. Palacio-Rua KA, Isaza-Jimenez LF, Ahumada-Rodriguez $E_{\text {, }}$ Muneton-Pena CM. Genetic analysis in APC, KRAS, and TP53 in patients with stomach and colon cancer. Rev Gastroenterol Mex. 2014;79(2):79-89. PMID: 24861525. Available from: https://doi.org/10.1016/j.rgmxen.2014.06.006.

31. Eshghifar N, Farrokhi N, Naji T, Zali M. Tumor suppressor genes in familial adenomatous polyposis. Gastroenterol Hepatol Bed Bench. 2017;10(1):3-13.

32. Hadziavdic V, Eminovic I, Asceric M, Komel R. Familial adenomatous polyposis: analysis of genetic instability of microsatellites Loci and genetic alternations of tumor suppressor genes. Bosn J Basic Med Sci. 2008;8(2):160-164. PMID: 18498268 Available from: https://doi.org/10.17305/bjbms.2008.2974.

33. Gao XH, Li J, Gong HF, Yu GY, Liu P, Hao LQ, et al. Comparison of Fresh Frozen Tissue With Formalin-Fixed ParaffinEmbedded Tissue for Mutation Analysis Using a Multi-Gene Panel in Patients With Colorectal Cancer. Front Oncol. 2020;10:310. PMID: 32232001. Available from: https://doi.org/ 10.3389/fonc.2020.00310.

34. Ye J, Lin M, Zhang C, Zhu X, Li S, Liu H, et al. Tissue gene mutation profiles in patients with colorectal cancer and their clinical implications. Biomed Rep. 2020;13(1):43-48. PMID 32440349. Available from: https://doi.org/10.3892/br.2020. 1303.

35. Ye ZL, Qiu MZ, Tang T, Wang F, Zhou YX, Lei MJ, et al. Gene mutation profiling in Chinese colorectal cancer patients and its association with clinicopathological characteristics and prognosis. Cancer Med. 2020;9(2):745-756. PMID: 31782259. Available from: https://doi.org/10.1002/cam4.2727.

36. Siraj AK, Kumar Parvathareddy S, Pratheeshkumar P, Padmaja Divya S, Ahmed SO, Melosantos R, et al. APC truncating mutations in Middle Eastern Population: Tankyrase inhibitor is an effective strategy to sensitize APC mutant CRC To 5FU chemotherapy. Biomed Pharmacother. 2020;121:109572. PMID: 31704613. Available from: https://doi.org/10.1016/j. biopha.2019.109572.

37. Conlin A, Smith G, Carey FA, Wolf CR, Steele RJ. The prognostic significance of K-ras, p53, and APC mutations in colorectal carcinoma. 2005;54(9):1283-1286. PMID: 15843421. Available from: https://doi.org/10.1136/gut.2005.066514. 